\title{
Pretreatment of drinking water from the low power surface water sources
}

\author{
Zhanna M. Govorova ${ }^{1, *}$, Alexander P. Svintsov ${ }^{2}$, Makhmud Kharun ${ }^{2}$ \\ ${ }^{1}$ Department of Water Supply, Moscow State University of Civil Engineering, Moscow, Russia \\ ${ }^{2}$ Department of Architecture and Civil Engineering, RUDN University, Moscow, Russia
}

\section{A R T I C L E IN F O}

\section{Article history:}

Received 3 March 2017

Received in revised form

25 September 2017

Accepted 28 September 2017

Keywords:

Phytoplankton

Prefilter with floating bed

Oxidizing agents

Coagulation

Technological model

\section{Introduction}

The problem of providing the drinking water to the small localities is especially acute in the areas with a shortage of fresh water. The deliveries of the imported water to the population are an expensive way of the water supply organization. Small freshwater lakes can be used as an alternative source. Water bodies, which were formed as a result of the regulation of small rivers, can also be used for the water supply. These solutions of water supply can be justified and appropriate in the sanitaryhygienic and the economic aspects. At the same time, the most complicated scientific and practical tasks during the use of such water sources are as (Govorova and Zhurba, 2012) (i) The selection and rationale of technological models of water treatment; (ii) the search for the necessary investments for the purchase of expensive equipment and reagents are the complicated scientific and practical task. It is due to the fact that the quality of drinking water, supplied to the population, is an essential breakdown of human health (Tomlinson et al., 2016). The pretreatment of drinking water from the small water sources is a complicated task because of the quality of raw water, the funding needs to provide the basic, and

\footnotetext{
* Corresponding Author.

Email Address: fonsvit@bk.ru (Z. M. Govorova)

https://doi.org/10.21833/ijaas.2017.011.021

2313-626X/C) 2017 The Authors. Published by IASE.

This is an open access article under the CC BY-NC-ND license

(http://creativecommons.org/licenses/by-nc-nd/4.0/)
}

especially, circulating capital (Zanacic et al., 2016). The ways to solve this problem are the following:

- to perform an analysis of the dynamic of changes in source water quality;

- to identify the possibility of applying the most efficient water treatment technologies for small water supply systems;

- to substantiate the least energy-consuming methods and water treatment facilities in the first stage of its treatment;

- to identify the initial data for the design of industrial water treatment plants and to perform a feasibility study on the basis of field studies.

In most cases, the small water bodies are characterized by the abundance of phytoplankton as the natural factor. The research of Zamyadi et al. (2013), Zhong et al. (2011), and Bowling et al. (2016) are devoted to the problem of solution of phytoplankton and cyanobacteria. It shows that the amount of cyanobacteria cells in the raw water can reach 4 to $6.9 \times 10^{5}$ cells/l. It influences significantly on the quality of raw water and the choice of its processing technology. Different methods of mechanical (Velten et al., 2011; Ding et al., 2016) and chemical (Matthijs et al., 2012; Van Nevel et al., 2012) exposure are used to counter the phytoplankton.

The comprehensive treatment of raw water from the small surface sources is a challenging task with the high cost of the finished product, which is the drinking water. It was experimentally established that before the coagulation, the colored water should 
be subjected to the prior oxidation. The most appropriate is the use of $\mathrm{O}_{3}$ and $\mathrm{H}_{2} \mathrm{O}_{2}$ or $\mathrm{NaOCl}$. $\mathrm{Al}_{2}\left(\mathrm{SO}_{4}\right)_{3} \cdot 18 \mathrm{H}_{2} \mathrm{O}$ or $\mathrm{FeCl}_{3} \cdot 6 \mathrm{H}_{2} \mathrm{O}$ can be used as the coagulating agent.

We developed technological models of the colored water treatment with the two-stage sequential filtration, the introduction of sodium hypochlorite solution and the subsequent coagulation. The proposed technological models allow carrying out the efficient pretreatment of drinking water from low power surface sources.

\section{Research sites}

We studied the specificity of formation of the water quality in water sources with a limited debit in the lake Staroe (the maximum length is about $2 \mathrm{~km}$ and the maximum depth - up to $3.5 \mathrm{~m}$ ), located in the southern part of the West Siberian Plain, and in the river Malaya Karla, located in the Republic of Kazan in Russia, which are the only local surface water source for the settlements with the population of about 8,000 and 10,000 people accordingly. The quality of these lake and river waters is formed under the influence of natural and anthropogenic factors. A large number of organic contaminants come from:

- the poorly treated household wastewater;

- the rain and snowmelt wash off from the surface of the catchment areas of organic contaminants and biogenic substances.

It leads to the eutrophication of the surface water source accompanied by the excessive development of phytoplankton. The number of micro-algae in some periods of the year reaches $60-100$ thousand cells/ml, and biomass - up to $20 \mathrm{mg} / \mathrm{l}$. The mass development and the death of micro-algae lead to increase in the quantity of suspended matters and in chromaticity in water bodies. Thus, the concentration of organic and bacterial contamination is increased. Some actinomycetes and mold fungi serve as the basis for rotting process, and the appearance of unpleasant smells and tastes of water which can reach up to 3-4 points (Skriabin et al., 2015; Sheveleva and Vorobyova, 2009).

\section{Results and discussion}

Usually, the operating water supply stations use a high chlorine pretreatment (doses up to 6-10 mg/l). Then the water is passed through the microfilters and the disc sieves, with further reagent precipitation and filtration (Kulsky, 1980; Kozlov et al., 2014). The pre-chlorination of water destroys the cell walls of phytoplankton and deprives it of buoyancy. Thus, the quantity of organic contaminants in water increases and its organoleptic properties deteriorate. The presence of chlororganic compounds in drinking water is strictly regulated by the sanitary standards. Further chemical treatment with using of coagulants and flocculants with higher doses leads to an over expenditure. The application of flotation, after the coagulation, in some cases allows improving the efficiency of the water purification from the low power surface water bodies. A large quantity of sediment forms as a result of flotation. This sediment has 99 to $99.5 \%$ humidity, which is poorly compacted and capable to decay. The dewatering and the utilization of such sediment cause some difficulties. The application of microfilters and disc sieves requires the considerable maintenance cost to ensure a guaranteed level of the water purification from phytoplankton. An alternative way to these methods is the detention of phytoplankton in the layers of floating bed of the prefilter, at a nonchemical filtering of water, from the bottom to the top, and for washing from the top to the bottom.

Our research of the efficiency of algae detention, which contains in the source water, at different speeds of the rising filtration through the EPS floating bed on the model of prefilter (Fig. 1), found that the effect of removing the algae biomass can be achieved up to $45.1-48.7 \%$ at the speeds of filtration up to $40-50 \mathrm{~m} / \mathrm{h}$. The reduction of filtration rates up to $30 \mathrm{~m} / \mathrm{h}$ allows increasing the effect of biomass cleaning up to $49.9-52.6 \%$ at its initial quantity in the water up to $26.2-66 \mathrm{mg} / \mathrm{l}$ and the quantity of cells up to 14-30.7 thousand cells/ml. The majority of the detained contaminants in prefilter were taken out at

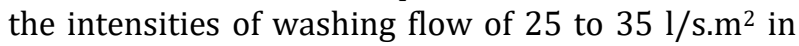
the first 5-6 minutes of washing. This fact was specified by the curves of removal of the detained biomass at a filtration cycle in EPS bed of prefilter and the quantity of algae and suspended matters during the washing, which were performed with different intensities at different values of contaminant layer at the end of the filtration cycle.The use of oxidizing agents in the technological process at a later stage of water treatment is justified by their role in ensuring the efficiency of the subsequent processes of coagulation and flocculation of contaminants in the source water. The study of these processes was carried out on the colored water of the artificially regulated area of the river Malaya Karla.

First, we studied the effect of oxidizing agents, the coagulant - aluminum oxychloride of brand "Aqua Aurat ${ }^{\mathrm{TM}}$ (AOC) and the flocculant - "Praestol 650TR" on the stability of colloidal particles of dispersed phase of the investigated water.

For this, the initial water was subjected to the treatment of water separately with ozone $\left(\mathrm{O}_{3}\right)$, hydrogen peroxide $\left(\mathrm{H}_{2} \mathrm{O}_{2}\right)$, sodium hypochlorite $(\mathrm{NaOCl})$, and also the combined effect of $\mathrm{H}_{2} \mathrm{O}_{2}$ and $\mathrm{O}_{3}$. Next, the optimal dose of AOC was determined through the coagulation test of oxidized water in accordance with the standard method at the dosage range of coagulant (Dc) from 5 to $50 \mathrm{mg} / \mathrm{l}$ on $\mathrm{Al}_{2} \mathrm{O}_{3}$, and flocculant $\left(D_{F}\right)$ from 0.05 to $0.5 \mathrm{mg} / \mathrm{l}$. The kinetic stability of the particles of suspended matter in water before and after its co-processing by oxidants were evaluated by the change in the value of the $\zeta$ potential, which was determined by amperometry by 
micro-electro-phoretic mobility of colloidal particles in the electric field.

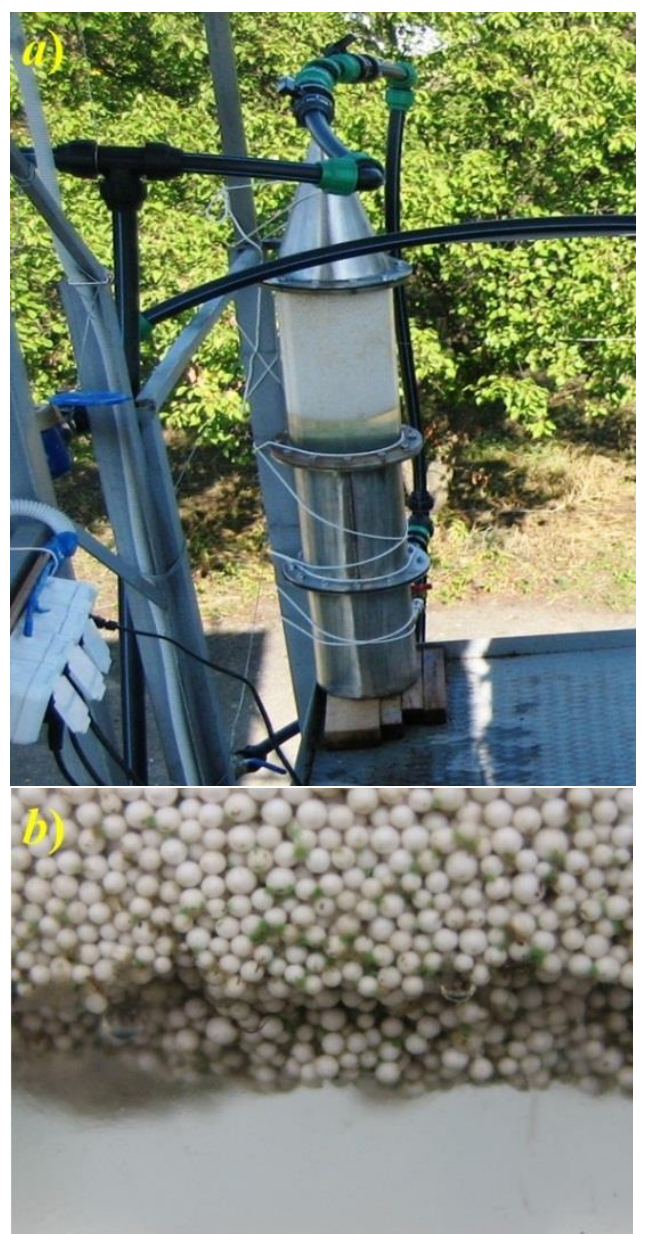

Fig. 1: Model of prefilter: $a$ ) side view; $b$ ) a fragment of EPS floating bed with detained algae

The comparison of the recharging process of $\zeta$ potentials of the colloid particles for the same colored source water, pretreated with different oxidizing agents in certain combinations of doses and concentrations, and then with the solution of AOC with $\mathrm{D}_{\mathrm{C}}$ of 5 to $50 \mathrm{mg} / \mathrm{l}$ on $\mathrm{Al}_{2} \mathrm{O}_{3}$ and flocculant with $D_{F}=0.5 \mathrm{mg} / \mathrm{l}$, showed the degree of influence of individual oxidizing agents on the processes of coagulation of contaminants. The most significant influence on the reduction of doses of coagulants showed the preliminary co-processing of water with ozone and hydrogen peroxide. The obtained research results have confirmed the technological feasibility of pre-oxidation of colored natural surface waters with $\mathrm{O}_{3}$ and $\mathrm{H}_{2} \mathrm{O}_{2}$ or $\mathrm{NaOCl}$, before its coagulation. The specificity of the physical and chemical composition of water in the water bodies with small debit calls for studying the processes of coagulation and flocculation after the application of oxidizing agents. However, their effect after the application of strong oxidizing agents (sodium hypochlorite, solution of oxidants, hydrogen peroxide, potassium permanganate, etc.) has not been studied enough. Feature of water quality, in which the processes of coagulation and flocculation were studied, is shown in Table 1.
Table 1: Quality indicators of source water from different water sources and in model solution

\begin{tabular}{cccc}
\hline \multirow{2}{*}{ Indicators } & \multicolumn{2}{c}{ Water Sources } & \multirow{2}{*}{$\begin{array}{c}\text { Model } \\
\text { solution }\end{array}$} \\
\cline { 2 - 3 } & $\begin{array}{c}\text { Lake } \\
\text { Staroe }\end{array}$ & $\begin{array}{c}\text { River Malaya } \\
\text { Karla }\end{array}$ & \\
\hline Smell, TON & $3-4$ & $2-3$ & $3-4$ \\
Turbidity, mg/l & $4-27.3$ & $40-93$ & $2.2-22.9$ \\
Chromaticity, & $23-115$ & $250-320$ & $26-170$ \\
Permanganate & $7.5-27.9$ & $12-19.7$ & $7.4-8.2$ \\
oxidizability, mgO $_{2} / \mathrm{l}$ & & & \\
Ammonia nitrogen, & $0,4-0,7$ & $2-4.8$ & $1.8-2.2$ \\
mg/l & $7.8-9.9$ & $7.1-8.2$ & $7.8-8.5$ \\
pH & $3.9-8.0$ & not & $1.8-3$ \\
Alkalinity, meq/l & measured & $244-442$ \\
Redox potential, mV & 122.4 & 31 & \\
\hline
\end{tabular}

We used the $4 \%$ solution of AOC as the coagulant in our study. The doses on $\mathrm{Al}_{2} \mathrm{O}_{3}$ were assigned in the ranges of $2.5,5.0,7.5,10,15$ and $20 \mathrm{mg} / \mathrm{l}$. The trial coagulation was carried out by the standard method. The results of the trial coagulation on the efficiency of sediment waters from different water sources on the turbidity, chromaticity and permanganate oxidability showed that the range of required dosages of coagulant for these waters is in the range of 10 to $30 \mathrm{mg} / \mathrm{l}$ on $\mathrm{Al}_{2} \mathrm{O}_{3}$. The values of Redoxpotential, as the measures of the ability of the chemical substance to join the electrons, and $\zeta$ potential, determined in the range of trial doses of coagulant, reached their maximum values +320 and $+40 \mathrm{mV}$ respectively.

The high molecular synthetic flocculants with molecular weight of $10^{4}$ to $10^{7}$, including "Praestol 650TR" and the poly diallyl dimethyl ammonium chloride (polyDADMAC) are the most common in the practice of the purification of natural surface water.

The initial water (Table 1) was subjected to the pre-chlorination with active chlorine dose of 2.5 $\mathrm{mg} / \mathrm{l}$ and coagulation of $4-5 \%$ solution of aluminum sulfate. As a result of tests, the coagulant dose was set in the range of 22 to $36 \mathrm{mg} / \mathrm{l}$.

In addition to the coagulant, the flocculant "Praestol 650TR" and organic coagulant polyDADMAC were used. Addition of $0.01 \%$ solution of polyDADMAC with the required fixed dose of 0.4 $\mathrm{mg} / \mathrm{l}$ has allowed reducing the required dose of aluminum sulfate from 36 to $22 \mathrm{mg} / \mathrm{l}$ without a substantial deterioration of water quality on permanganate oxidability while improving its chromaticity and turbidity.

The loss of stability of colloidal system was determined by the change in the polarization of charges and the increase in the $\zeta$-potential. The comparison of the efficiency of polyDADMAC with the flocculant "Praestol 650TR" showed that in case of its application with the coagulant dose of $22 \mathrm{mg} / \mathrm{l}$, the effect of the subsequent sedimentation of water on the basic indicators of quality was slightly higher. However, in this case, its working dose was about 5 times higher as compared with flocculant "Praestol 650TR".

Analysis of some water treatment technologies of the water sources with high anthropogenic load, proposed by Draginsky et al. (2005), showed that 
when using the water sources of eutrophic water bodies with a limited debit, the requirements for their sanitary reliability is often increased.

Studies of water pretreatment process, before its entering to the main treatment structures, allowed to develop an improved technological model (model 1) of pretreatment of drinking water from the low power water sources (Govorova and Magomadov, 2012). It is different from the well-known technologies by using of prefilters with floating EPS bed, oxidizing agents, coagulants and flocculants in its composition, and also two-stage decoloring sorption filters (DSF) and decontamination by ultraviolet radiation with ultrasound and solution of sodium hypochlorite. Formation of the layer of combined loading in DSF was carried out by introducing the small-granule sorbent in the top layer of EPS at the last stage of washing (Pokrovsky and Govorova, 2000).

The technological model should be supplied by the post-ozonization and the sorption, if there are the considerable permanent anthropogenic loads on the water source (model 2). In this case, only inert loadings are used in the two-stage contact filters. Fig. 2 presents the fragments of water pretreatment plant with the capacity of up to $600 \mathrm{~m}^{3} /$ day.
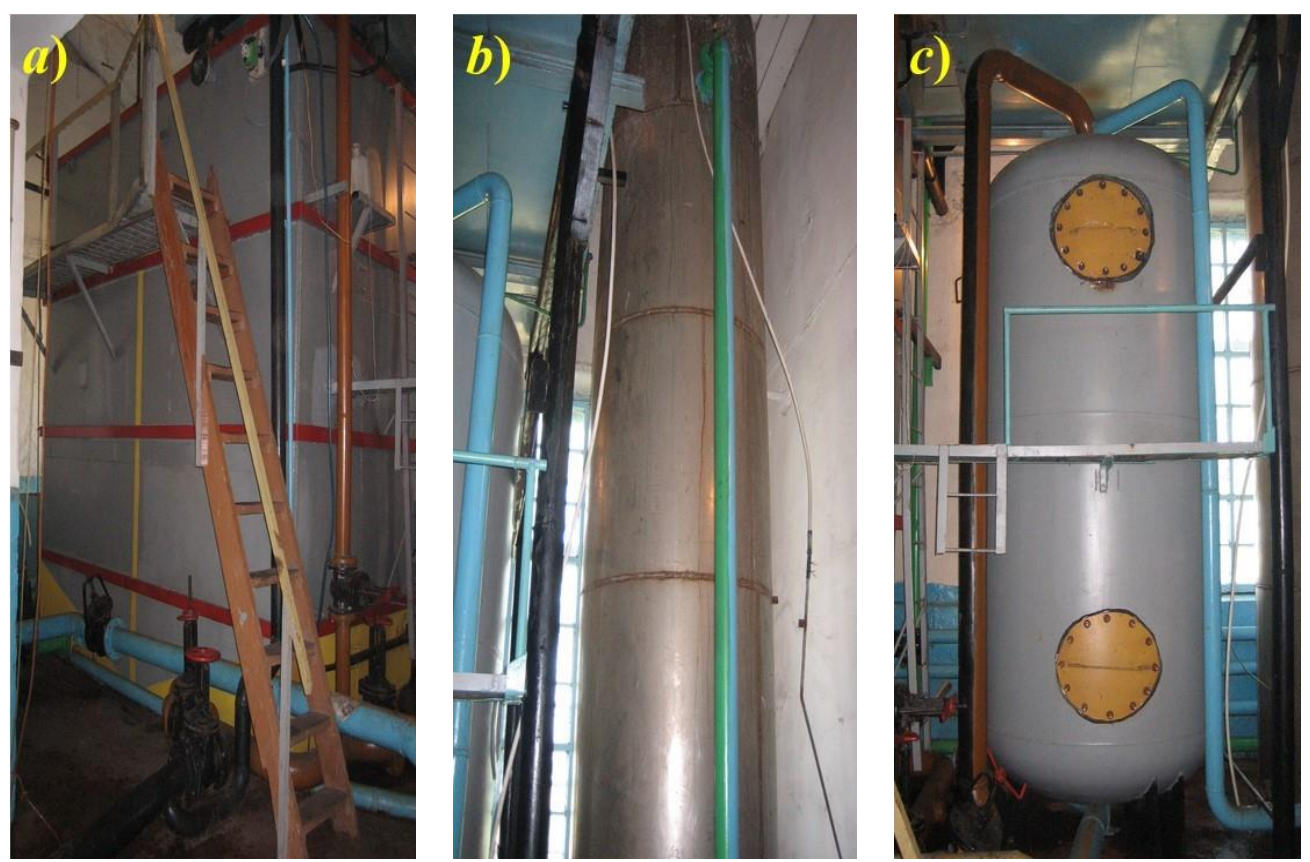

Fig. 2: Water pretreatment plant; a) two-stage decoloring filter with inert loadings; b) contact column of post-ozonization; c) sorption filter

Farther, we developed technological model with two-stage sequential filtration of water (model 3) and by preliminary input of sodium hypochlorite solution with active chlorine dose of 5.8 to $8.8 \mathrm{mg} / \mathrm{l}$, by coagulation with doses of $3 \%$ AOC solution in the quantity of 10 to $15 \mathrm{mg} / \mathrm{l}$ in the primary coagulation, and in the secondary (in some filtration cycles) -6.4 to $7 \mathrm{mg} / \mathrm{l}$ with the addition of flocculant "Praestol $650 \mathrm{TR} "$ in a quantity of up to $0.5 \mathrm{mg} / \mathrm{l}$. It allows to provide the deep water treatment not only on turbidity and chromaticity, but also on iron and manganese, decrease of which, as of residual aluminum, was occurred due to the presence of second stage catalyst-adsorbent of brand $\mathrm{MC}^{\text {тм }}$ as a part of filter loading (Zhurba et al., 2009). Application scope of the proposed improved technologies according to the models of 1 to 3 is shown in Table 2, and the basic economic indicators in Table 3 (Govorova and Magomadov, 2012).

\section{Conclusion}

The analysis of water quality was performed, and their specificity, based on two surface water sources with limited debits was determined.
Table 2: Application scope of the proposed water pretreatment technologies

\begin{tabular}{cccc}
\hline \multirow{2}{*}{ Indicators } & \multicolumn{3}{c}{ Technological Models } \\
\cline { 2 - 4 } & Model 1 & Model 2 & Model 3 \\
\hline Productive capacity, thousand & $250-$ & $1000-$ & $250-$ \\
$\mathrm{m}^{3} /$ day & 1000 & 5000 & 5000 \\
Smell, TON & $2-3$ & $3-4$ & $2-3$ \\
Turbidity, mg/l & $5-30$ & $5-30$ & 50 \\
Chromaticity, & $25-150$ & $25-150$ & 180 \\
Permanganate oxidizability, & $10-12$ & $15-20$ & $12-15$ \\
mgO $_{2} / \mathrm{l}$ & $1-3$ & $1-2$ & $2-3$ \\
Iron, mg/l & $0.1-0.2$ & $0.1-0.2$ & $0.5-1.0$ \\
Manganese, mg/l & $14-35$ & $14-35$ & $15-30$ \\
Phytoplankton, thousand & & & \\
cells/l & &
\end{tabular}

Table 3: Economic indicators for the water treatment plant of the productive capacity of $1500 \mathrm{~m}^{3} /$ day in the condition of Russia

\begin{tabular}{cccc}
\hline & \multicolumn{3}{c}{ Technological Models } \\
\cline { 2 - 4 } Indicators & Model & Model & Model \\
& 1 & 2 & 3 \\
\hline Initial investment, thousand USD & 730 & 870 & 925 \\
Operational cost, thousand USD & 270 & 385 & 415 \\
Payback period, years & 4 & 4 & 4 \\
Cost for water pretreatment, & 0.5 & 0.7 & 0.8 \\
USD $/ \mathrm{m}^{3}$ & & & \\
\hline
\end{tabular}

The experimental research results show the essential role of water pretreatment, which are 
aimed to remove the algae and the oxidation of organic contaminants before the subsequent coagulation and flocculation of water.

The advanced technological models of pretreatment of drinking water from the low power water sources, depending on the range of concentrations of contaminants are proposed and their effective application scope is determined.

\section{References}

Bowling LC, Zamyadi A, and Henderson RK (2016). Assessment of in situ fluorometry to measure cyanobacterial presence in water bodies with diverse cyanobacterial populations. Water Research, 105: 22-33.

Ding Q, Yamamura H, Murata N, Aoki N, Yonekawa H, Hafuka A, and Watanabe Y (2016). Characteristics of meso-particles formed in coagulation process causing irreversible membrane fouling in the coagulation-microfiltration water treatment Water Research, 101: 127-136.

Draginsky VL, Alekseeva LP, and Getmantsev SV (2005). Coagulation in the purification technology of natural water. Scientific Publication, Moscow, Russia. Available online at: https://elibrary.ru/item.asp?id=19624909

Govorova ZM and Magomadov ZR (2012). Pretreatment of water from the shallow reservoirs. Vodosnabzhenie i sanitarnaya tekhnika [Water Supply and Sanitary Engineering], 2: 62-70. Available online at: https://elibrary.ru/item.asp?id= 17355175

Govorova ZM and Zhurba MG (2016). Substantiation of water treatment technologies and their investments. Scientific Publication. Vologda State Technical University, Vologda, Russia. Available online at: https://elibrary.ru/item.asp?id= 27361140

Kozlov MN, Arutyunova I, Yagunkov S, Arbuzov R, Abramov S, and Basikhin P (2014). Prospective method of the removal of phytoplankton. Zhunal Voda [Journal of Water], 1: 18-25. Available online at: https://elibrary.ru/title_about.asp?id= 32203

Kulsky LA (1980). Theoretical foundations and the technology of water conditioning: Processes and equipment. Naukova Dumka, Kiev, Ukraine. Available online at: https://elibrary.ru/item.asp?id=20739575

Matthijs HC, Visser PM, Reeze B, Meeuse J, Slot PC, Wijn G, Talens R, and Huisman J (2012). Selective suppression of harmful cyanobacteria in an entire lake with hydrogen peroxide. Water Research, 46(5): 1460-1472.

Pokrovsky MS and Govorova ZM (2000). Decolouring-sorption filter. Vodosnabzhenie i sanitarnaya tekhnika [Water Supply and Sanitary Engineering], 7: 7-11.

Sheveleva NG and Vorobyova SS (2009). Status and development of phyto- and zooplankton of the lower portion of the river Angara, the forecast of formation of plankton in Boguchany reservoir. Journal of the Siberian Federal University - Biology 3, 2: 313-325. Available online at: https://elibrary.ru/item.asp?id=13013670

Skriabin AY, Popovyan GV, and Tron IA (2015). Microalgae as a factor of affecting the organoleptic properties of water of the river Don. Vodosnabzhenie i sanitarnaya tekhnika [Water Supply and Sanitary Engineering], 8: 38-41.

Tomlinson A, Drikas M, and Brookes JD (2016). The role of phytoplankton as pre-cursors for disinfection by-product formation upon chlorination. Water Research, 102: 229-240.

Van Nevel S, Hennebel T, De Beuf K, Du Laing G, Verstraete W, and Boon N (2012). Transparent exopolymer particle removal in different drinking water production centers. Water Research, 46(11): 3603-3611.

Velten S, Boller M, Köster O, Helbing J, Weilenmann HU, and Hammes F (2011). Development of biomass in a drinking water granular active carbon (GAC) filter. Water Research, 45(19): 6347-6354.

Zamyadi A, Dorner S, Sauvé S, Ellis D, Bolduc A, Bastien C, and Prévost M (2013). Species-dependence of cyanobacteria removal efficiency by different drinking water treatment processes. Water Research, 47(8): 2689-2700.

Zanacic E, Stavrinides J, and McMartin DW (2016). Field-analysis of potable water quality and ozone efficiency in ozoneassisted biological filtration systems for surface water treatment. Water Research, 104: 397-407.

Zhong F, Gao Y, Yu T, Zhang Y, Xu D, Xiao E, He F, Zhou Q, and Wu Z (2011). The management of undesirable cyanobacteria blooms in channel catfish ponds using a constructed wetland: Contribution to the control of off-flavor occurrences. Water Research, 45(19): 6479-6488.

Zhurba MG, Govorova ZM, Kulikovsky VA, Gladky AI, and Magomadov ZR (2009). Pretreatment of drinking water from the regulated water sources with a high content of organic substances. Vodosnabzhenie i kanalizatsiya [Water Supply and Sewerage], 7: 43-49. 